\title{
FAKTOR-FAKTOR YANG BERHUBUNGAN DENGAN KUALITAS HIDUP PEREMPUAN KLIMAKTERIK
}

\author{
Yanita Trisetiyaningsih ${ }^{1}$ \\ ${ }^{1}$ Stikes Jenderal Achmad Yani Yogyakarta \\ Jl. Ringroad Barat, Ambarketawang, Gamping, Sleman, D.I.Yogyakarta \\ E-mail: ners_yanita@yahoo.co.id
}

\begin{abstract}
Background:Physical and psychological changes during climacterium phase could influence quality of life in climacteric women. Eightypercent of womenreported anydiscomfortthat occurs as climactericsymptomssuch asheadaches, sexual problems, tachycardia, hot flushes, sweatingandinsomniathat can significantlydegrade the quality oflive. Factorsthat determinethe quality of lifeare age, menopauseduration, marital status, education level, income, employment status, healthstatus, health insurance, and parity.

Objective: The purpose of the study was to determine thefactorsassociated withthe quality of life ofclimactericwomen.

Methods: The study wasa quantitave research with cross sectional design. The samples were 88 subjects. Data collection used Menopause Rating Scale (MRS) and the WHOQOL-BREF.The data analysis used Spearman rank correlation test and contingency coefficient.

Result: There was a significant relationship between parity and employment status with quality of life $(p<0.05)$, but not to the variables of age, duration of menopause, marital status, education level, income, and health insurance.
\end{abstract}

Conclusion: There was a significant relationship between parity and employment status with quality of lifein climacteric women.

Keyword: quality of life, climacteric women

\section{PENDAHULUAN}

Menopause merupakan hal yang secara fisiologis akan dialami oleh seorang perempuan. Perempuan akan mengalami berbagai perubahan baik secara fisik maupun psikologis. Adanya perubahan perubahan tersebut akan memengaruhi kualitas hidup perempuan di masa klimakterium. Delapan puluh persen perempuan melaporkan adanya ketidaknyamanan gejala yang terjadi saat klimakterium seperti sakit kepala, masalah seksual, takikardi, hot flushes, berkeringat, dan insomnia yang secara signifikan dapat menurunkan kualitas hidup. ${ }^{(1)}$

Berdasarkan penelitian yang telah dilakukan sebelumnya didapatkan hasil bahwa 22,7\% perempuan klimakterik tidak menunjukkan gejala, $36,4 \%$ mengalami gejala yang sedang sehingga diperlukan modifikasi perilaku dan gaya hidup, dan $36,4 \%$ mengalami gejala yang berat. Selain gejala klimakterik, dalam penelitian ini juga didapatkan hasil bahwa $30 \%$ wanita klimakterik mengalami gangguan fisik, 10\% mengalami gangguan psikologis, dan 15\% mengalami stres. ${ }^{(2)}$ Untuk itu diperlukan proses adaptasi terhadap berbagai masalah dan perubahan selama masa klimakterium sehingga mampu meningkatkan kualitas hidup perempuan pada masa klimakterium.

Beberapa faktor yang memengaruhi gejala menopause antara lain gaya hidup, etnis, status menstruasi, status sosial ekonomi, kejadian negatif di masa lalu, 
sumber personal, dan kepribadian. ${ }^{(3,4)}$ Gejala menopause dan kualitas hidup perempuan klimakterik merupakan konsep yang berhubungan erat. Berat ringannya gejala menopause yang dialami oleh perempuan klimakterik akan berdampak terhadap kualitas hidup.

WHO mendefinisikan kualitas hidup sebagai persepsi individu terhadap kehidupannya di masyarakat dalam konteks budaya dan norma yang ada, dan berkaitan dengan tujuan, harapan, standar, dan kepedulian selama hidupnya. ${ }^{(5)}$ Beberapa faktor yang menentukan kualitas hidup yaitu usia, lama menopause, gejala menopause, status pernikahan, tingkat pendidikan, penghasilan, pekerjaan, status kesehatan, asuransi kesehatan, paritas. ${ }^{(6)}$ Rumusan masalah yang diambil oleh peneliti adalah faktor apa saja yang berhubungan dengan kualitas hidup perempuan klimakterik. Tujuan dari penelitian ini adalah untuk mengetahui faktor-faktor yang berhubungan dengan kualitas hidup perempuan klimakterik.

\section{BAHAN DAN CARA PENELITIAN}

Penelitian ini menggunakan jenis penelitian kuantitatif dengan metode pendekatan non eksperimental dengan rancangan cross sectional (potong lintang). Dalam penelitian ini populasi yang digunakan adalah semua perempuan klimakterik usia 45-60 tahun di Dusun Gamping Kidul Ambarketawang Gamping Sleman Yogyakarta. Sampel yang dibutuhkan berjumlah 88 orang. Pengambilan sampel dilakukan dengan metode simple random sampling.

Kriteria inklusi dalam penelitian ini antara lain bersedia menjadi responden, berstatus menikah, telah mengalami tanda dan gejala klimakterium (menstruasi tidak teratur), tidak menggunakan terapi sulih hormon, tidak merokok, tidak melakukan histerektomi, tidak melakukan ooforektomi, bersedia mengikuti proses penelitian sampai akhir, BMI $<30 \mathrm{~kg} / \mathrm{m}^{2}$, tidak bekerja di unit pelayanan kesehatan, tidak memiliki penyakit kronis seperti hipertensi, diabetes mellitus, penyakit jantung, gagal ginjal, dan mampu membaca dan menulis. Sedangkan kriteria eksklusi dari penelitian ini meliputi mempunyai gangguan mental dan fisik, tidak mengikuti proses penelitian sampai akhir.

Data tentang kualitas hidup diukur dengan menggunakan kuesioner World Health Organization Quality of Life-Bref (WHOQOL-BREF) yang terdiri atas empat domain yaitu fisik, psikologis, sosial, dan lingkungan. Uji statistik analisis data menggunakan korelasi Spearman Rank (untuk variabel dengan skala ordinal dan ordinal) dan koefisien kontingensi (untuk variabel dengan skala nominal dengan ordinal).

\section{HASIL DAN PEMBAHASAN}

\section{A. Karakteristik Responden}

$\begin{array}{lcc}\text { Distribusi frekuensi } & \text { karakteristik } \\ \text { responden secara } & \text { keseluruhan } \\ \text { ditampilkan dalam tabel 1. } & \end{array}$


Tabel 1

Karakteristik Responden Berdasarkan Usia, Usia Menarche, Usia Menopause, Lama Menopause, Status Pernikahan, Tingkat Pendidikan, Penghasilan, Pekerjaan, Asuransi Kesehatan, Paritas( $\mathrm{n}=88)$

\begin{tabular}{|c|c|c|}
\hline Karakteristik & $\begin{array}{l}\text { Mean士SD } \\
\text { (Min-Max) }\end{array}$ & n (\%) \\
\hline Usia Saat ini (tahun) & $51,4 \pm 4,63(45-60)$ & \\
\hline Usia Menarche (tahun) & $13,5 \pm 1,48(10-18)$ & \\
\hline Usia Menopause (tahun) & $49,4 \pm 3,78(40-55)$ & \\
\hline \multicolumn{3}{|l|}{ Lama Menopause } \\
\hline Belum Menopause & & $43(48,9 \%)$ \\
\hline Menopause $<5$ tahun & & $24(27,2 \%)$ \\
\hline Menopause $\geq 5$ tahun & & $21(23,9 \%)$ \\
\hline \multicolumn{3}{|l|}{ Gejala menopause } \\
\hline Tidak ada/sedikit & & $8(9,1 \%)$ \\
\hline Ringan & & $44(50 \%)$ \\
\hline Sedang & & $32(36,4 \%)$ \\
\hline Berat & & $4(4,5 \%)$ \\
\hline \multicolumn{3}{|l|}{ Status pernikahan } \\
\hline Menikah & & $71(80,7 \%)$ \\
\hline Janda Mati & & $15(17 \%)$ \\
\hline Cerai & & $2(2,3 \%)$ \\
\hline \multicolumn{3}{|l|}{ Pendidikan } \\
\hline Rendah ( $\leq S D)$ & & $34(38,6 \%)$ \\
\hline Sedang (SMP-SMA) & & $48(54,5 \%)$ \\
\hline Tinggi ( $\geq$ Diploma/Strata 1) & & $6(6,9 \%)$ \\
\hline \multicolumn{3}{|l|}{ Penghasilan } \\
\hline Lebih dari UMK ( $\geq \operatorname{Rp} 1.127 .000)$ & & $45(51,1 \%)$ \\
\hline Kurang dari UMK (<Rp 1,127.000) & & $43(48,9 \%)$ \\
\hline \multicolumn{3}{|l|}{ Pekerjaan } \\
\hline Bekerja & & $39(43,2 \%)$ \\
\hline Tidak berpenghasilan & & $49(56,8 \%)$ \\
\hline \multicolumn{3}{|l|}{ Asuransi Kesehatan } \\
\hline Punya & & $46(52,3 \%)$ \\
\hline Tidak punya & & $42(46,7 \%)$ \\
\hline \multicolumn{3}{|l|}{ Paritas } \\
\hline Nullipara (anak hidup 0) & & $4(4,5 \%)$ \\
\hline Primipara (anak hidup 1) & & $9(10,2 \%)$ \\
\hline Multipara (anak hidup $\geq 2$ ) & & $75(85,3 \%)$ \\
\hline
\end{tabular}

Tabel 1 menunjukkan bahwa rata-rata usia responden adalah 51 tahun, ratarata menarche pada usia 13 tahun dan usia menopause rata-rata 49 tahun. Sebagian besar responden belum mengalami menopause namun sudah mengalami tanda klimakterium sebanyak 43 orang $(48,9 \%)$, menikah dan tinggal dengan pasangan sebanyak 71 orang
(80,7\%), memiliki tingkat pendidikan sedang sebanyak 48 orang $(54,5 \%)$, tidak bekerja sebanyak 49 orang (56,8\%), mempunyai asuransi sebanyak 46 orang $(52,3 \%)$, memiliki anak lebih dari 2 orang sebanyak 75 orang (85,3\%), dan memiliki gejala menopause dalam tingkat ringan sebanyak 44 orang (50\%). Untuk variabel tingkat penghasilan 
jumlah responden yang memiliki penghasilan lebih dari Upah Minimum Kabupaten (UMK) hampir sama jumlahnya dengan responden yang memiliki penghasilan kurang dari UMK.

B. Gambaran Kualitas Hidup perempuan Klimakterik

Distribusi frekuensi karakteristik responden secara keseluruhan ditampilkan dalam tabel 2.

Tabel 2

Gambaran Kualitas Hidup Perempuan Klimakterik di Dusun Gamping Kidul Ambarketawang Gamping Sleman

\begin{tabular}{ll}
\multicolumn{2}{c}{$(\mathbf{n = 8 8 )}$} \\
\hline Karakteristik & $\mathrm{n}(\%)$ \\
\hline Kualitas Hidup & \\
Cukup (25-49) & 29 \\
& $(32,9 \%)$ \\
Baik (50-74) & 59 \\
& $(67,1 \%)$ \\
\hline
\end{tabular}

Sebagian besar responden mempunyai kualitas hidup baik $(67,1 \%)$. Kualitas hidup adalah persepsi individu terhadap kehidupannya di masyarakat dalam konteks budaya dan norma yang ada dan berkaitan dengan tujuan, harapan, standar, dan kepedulian selama hidupnya. ${ }^{(5)}$ Kualitas hidup bisa diukur melalui empat domain utama yaitu fisik, psikologis, sosial, dan lingkungan. Beberapa faktor yang menentukan kualitas hidup antara lain jenis kelamin, umur, etnis/ras, status pernikahan, pendidikan, penghasilan, status kesehatan, asuransi kesehatan, serta faktor kesehatan. ${ }^{(6)}$
Perempuan klimakterik yang masuk dalam responden penelitian ini berusia 45-60 tahun. Dalam rentang usia tersebut, secara fisiologis seorang wanita telah mengalami penurunan fungsi hormon reproduksi sehingga berpengaruh dalam siklus menstruasi sampai akhirnya berhenti pada satu masa di mana seorang perempuan tidak mengalami menstruasi lagi (menopause). Pada rentang usia tersebut gejala atau keluhan menopause sudah mulai muncul. Untuk itu diperlukan kesiapan mental dalam beradaptasi terhadap perubahan-perubahan yang muncul dalam menghadapi masa menopause. Ketidaknyamanan akibat perubahan fisik dan psikologis dapat memengaruhi kualitas hidup perempuan. Perubahan kualitas hidup perempuan klimakterik juga akan berdampak pada kehidupan pasangannya.

C. Hubungan Antara Usia Responden, Lama Menopause, Status Pernikahan, Tingkat Pendidikan, Penghasilan, Pekerjaan, Paritas, dan Kepemilikan Asuransi Kesehatan dengan Kualitas Hasil uji korelasi Spearman-Rank untuk variabel gejala menopause, tingkat pendidikan dan penghasilan ditampilkan pada tabel 3 . 
Tabel 3

Hasil Uji Korelasi Spearman Rank Antara Tingkat Pendidikan, Penghasilan dengan Kualitas Hidup $(n=88)$

\begin{tabular}{|c|c|c|c|c|c|}
\hline \multirow{3}{*}{ Variabel } & \multicolumn{3}{|c|}{ Kualitas Hidup } & \multirow{3}{*}{$p$-value } & \multirow{3}{*}{$r$} \\
\hline & Cukup & Baik & Sangat Baik & & \\
\hline & $\mathrm{n}(\%)$ & $n(\%)$ & $n(\%)$ & & \\
\hline \multicolumn{6}{|l|}{ Tingkat Pendidikan } \\
\hline Rendah ( $\leq \mathrm{SD})$ & $2(5,9 \%)$ & $32(94,1 \%)$ & $0(0 \%)$ & & \\
\hline Sedang (SMP-SMA) & $6(12,5 \%)$ & $39(81,3 \%)$ & $3(6,2 \%)$ & 0,929 & 0,010 \\
\hline Tinggi ( $\geq$ Diplola/Strata 1) & $1(16,7 \%)$ & $4(66,7 \%)$ & $1(16,6 \%)$ & & \\
\hline \multicolumn{6}{|l|}{ Penghasilan } \\
\hline $\begin{array}{l}\text { Kurang dari UMK } \\
(<1,127.000)\end{array}$ & $3(7 \%)$ & $40(93 \%)$ & $0(0 \%)$ & & \\
\hline $\begin{array}{l}\text { Lebih dari UMK } \\
(\geq 1.127 .000)\end{array}$ & $6(13,3 \%)$ & $35(77,8 \%)$ & $4(8,9 \%)$ & 0,804 & 0,027 \\
\hline
\end{tabular}

Berdasarkan uji korelasi Spearman-Rank didapatkan hasil bahwa variabel tingkat pendidikan dan penghasilan tidak berhubungan secara signifikan dengan kualitas hidup.Hal ini dibuktikan dengan nilai $p>0,05$. Hubungan antara variabel usia, lama menopause, status pernikahan, status pekerjaan, paritas, dan asuransi kesehatan dengan kualitas hidup digunakan uji korelasi koefisien kontingensi, namun sebelumnya harus dilakukan uji Chi-Square. Hasil uji korelasi koefisien kontingensi untuk variabel usia, lama menopause, status pernikahan, status pekerjaan, paritas, dan asuransi kesehatan ditampilkan dalam tabel 4.

\section{Tabel 4}

Hasil Uji Korelasi Koefisien Kontingensi Antara Variabel Usia, Lama Menopause, Status Pernikahan, Status Pekerjaan, Paritas, dan Asuransi Kesehatan dengan Kualitas Hidup ( $\mathbf{n = 8 8})$

\begin{tabular}{|c|c|c|c|c|c|c|}
\hline \multirow{3}{*}{ Variabel } & \multicolumn{3}{|c|}{ Kualitas Hidup } & \multirow{3}{*}{$p$-value } & \multirow{3}{*}{$x^{2}$} & \multirow{3}{*}{$C$} \\
\hline & Cukup & Baik & $\begin{array}{l}\text { Sangat } \\
\text { Baik }\end{array}$ & & & \\
\hline & n (\%) & $\mathrm{n}(\%)$ & $\mathrm{n}(\%)$ & & & \\
\hline \multicolumn{7}{|l|}{ Usia } \\
\hline Pralansia 45-50 tahun & $5(11,6 \%)$ & $36(83,7 \%)$ & $2(4,7 \%)$ & 0,541 & 1,228 & 0,165 \\
\hline \multicolumn{7}{|l|}{ Lama Menopause } \\
\hline Belum Menopause & $5(11,6 \%)$ & $35(81,4 \%)$ & $3(7 \%)$ & 0,229 & 5,623 & 0,337 \\
\hline Menopause $<5$ tahun & $1(4,2 \%)$ & $23(95,8 \%)$ & $0(0 \%)$ & & & \\
\hline Menopause $\geq 5$ tahun & $3(14,3 \%)$ & $17(81 \%)$ & $1(4,7 \%)$ & & & \\
\hline \multicolumn{7}{|l|}{ Status pernikahan } \\
\hline Menikah & $6(8,5 \%)$ & $61(85,9 \%)$ & $4(5,6 \%)$ & & & \\
\hline Janda mati & $3(20 \%)$ & $12(80 \%)$ & $0(0 \%)$ & 0,715 & 2,112 & 0,214 \\
\hline Cerai & $0(0 \%)$ & $2(100 \%)$ & $0(0 \%)$ & & & \\
\hline \multicolumn{7}{|l|}{ Status pekerjaan } \\
\hline Bekerja & $1(2,6 \%)$ & $35(89,7 \%)$ & $3(7,7 \%)$ & 0,023 & 7,503 & 0,382 \\
\hline Tidak bekerja & $8(16,3 \%)$ & $40(81,6 \%)$ & $1(2,1 \%)$ & & & \\
\hline \multicolumn{7}{|l|}{ Paritas } \\
\hline Nullipara & $0(0 \%)$ & $3(75 \%)$ & $1(25 \%)$ & & & \\
\hline Primipara & $1(11,1 \%)$ & $6(66,7 \%)$ & $2(22,2 \%)$ & 0,03 & 10,722 & 0,443 \\
\hline Multipara & $8(10,7 \%)$ & $66(88 \%)$ & $1(1,3 \%)$ & & & \\
\hline
\end{tabular}




\begin{tabular}{lllllll}
\hline Asuransi Kesehatan & & & & & \\
$\quad$ & $5(10,9 \%)$ & $38(82,6 \%)$ & $3(6,5 \%)$ & 0,684 & 0,760 & 0,130 \\
Punya & $4(9,5 \%)$ & $37(88,1 \%)$ & $1(2,3 \%)$ & & & \\
\hline
\end{tabular}

Berdasarkan hasil uji korelasi koefisien kontingensi didapatkan hasil bahwa variabel paritas berhubungan dengan kualitas hidup perempuan klimakterik dengan nilai $p<0,05$ dan $x^{2}$ hitung $(10,722)>x^{2}$ tabel $(9,488)$ dengan koefisien $C$ sebesar 0,443 . Variabel status pekerjaan juga berhubungan dengan kualitas hidup perempuan klimakterik dengan nilai $p<0,05$ dan $x^{2}$ hitung $(7,503)>x^{2}$ tabel $(5,5591)$ dengan koefisien $C$ sebesar 0,382.

\section{PEMBAHASAN}

Kualitas hidup perempuan klimakterik selain dipengaruhi oleh pendidikan kesehatan kemungkinan juga dipengaruhi oleh beberapa faktor lain seperti usia, lama menopause, gejala menopause, status pernikahan, tingkat pendidikan, penghasilan, status pekerjaan, paritas, dan kepemilikan asuransi kesehatan. Namun dalam penelitian ini hanya variabel pendidikan kesehatan dan paritas yang berhubungan secara signifikan dengan kualitas hidup $\left(p<0,05\right.$ dan $x^{2}$ hitung $>x^{2}$ tabel).

Pada penelitian ini usia tidak memiliki hubungan yang bermakna dengan kualitas hidup perempuan klimakterik. Hasil penelitian ini mendukung hasil penelitian sebelumnya yang menyatakan bahwa umur tidak berhubungan dengan kualitas hidup penderita kanker payudara pasca mastektomi. ${ }^{(7)}$ Kualitas hidup tidak berhubungan dengan umur. ${ }^{(8)}$ Hasil penelitian ini juga mendukung penelitian sebelumnya yang menyatakan bahwa usia tidak berpengaruh terhadap kualitas hidup perempuan premenopause dan pasca menopause. ${ }^{(9)}$

Usia berpengaruh signifikan terhadap beberapa domain kualitas hidup. ${ }^{(10)}$ Usia lebih dari 55 tahun akan berpengaruh secara signifikan terhadap domain fisik, psikologi, dan seksual. Sedangkan usia $<55$ tahun akan berpengaruh secara signifikan terhadap domain seksual saja. Perbedaan hasil penelitian ini dengan penelitian sebelumnya terletak pada penggunaan kuesioner kualitas hidup. ${ }^{(10)}$ Usia berpengaruh terhadap gejala perimenopause yang terjadi sesuai dengan periode menopause. ${ }^{(11)} \mathrm{Pada}$ penelitian ini baik kelompok usia 45-50 tahun maupun usia 51-60 tahun mayoritas mempunyai kualitas hidup yang baik sebanyak $83,7 \%$ pada kelompok usia 45-50 tahun dan 86,7\% pada kelompok usia 51-60 tahun.

Penelitian ini menunjukkan bahwa tidak ada hubungan antara lama menopause dengan kualitas hidup perempuan klimakterik. Tidak ada perbedaan kualitas hidup pada perempuan premenopause dan pasca menopause. ${ }^{(9)}$ Domain fisik tanpa keluhan vasomotor lebih tinggi pada perempuan yang mengalami menopause selama 1-5 tahun dan lebih dari 10 tahun. $^{(9)}$ 
Hasil penelitian ini juga mendukung penelitian sebelumnya yang menunjukkan hasil bahwa tidak ada hubungan lama menopause yang lebih dari 5 tahun terhadap kualitas hidup, sedangkan lama menopause kurang dari 5 tahun berpengaruh secara signifikan terhadap domain seksual saja. ${ }^{(10)}$ Lama menopause berdampak terhadap penyesuaian diri seorang perempuan terhadap perubahan-perubahan yang terjadi saat menopause. Pada masa kurang dari 5 tahun, seorang perempuan sedang beradaptasi terhadap gejala yang muncul saat menopause sehingga dapat berpengaruh terhadap kualitas hidup perempuan klimakterik. Sedangkan jika menopause lebih dari 5 tahun, seorang perempuan sudah melewati masa penyesuaian diri sehingga akan merasakan suatu keadaan yang sudah terbiasa. Keberhasilan dalam proses penyesuaian diri tersebutkan berpengaruh pula terhadap sikap, perilaku sehari-hari yang akan berefek terhadap kualitas hidup. Namun ada faktor lain yang turut berperan dalam proses penyesuaian diri terhadap perubahan selama menopause antara lain penghasilan, dukungan sosial, pekerjaan. Jadi lama menopause bukan faktor tunggal yang bisa memengaruhi kualitas hidup perempuan klimakterik.

Dalam penelitian ini sebagian besar responden baik yang mempunyai gejala menopause tingkat ringan, sedang, dan berat mempunyai kualitas hidup yang baik.Bahkan
3 orang yang memunyai gejala menopause ringan justru memiliki kualitas hidup cukup. Lain halnya dengan 4 orang responden yang memiliki gejala menopause berat justru memiliki kualitas hidup yang baik.

Hasil penelitian ini juga menunjukkan bahwa tidak ada hubungan antara status pernikahan terhadap kualitas hidup perempuan klimakterik. Hasil penelitian ini sesuai dengan penelitian sebelumnya yang menyatakan bahwa keberadaan pasangan tidak memengaruhi secara signifikan terhadap kualitas hidup. ${ }^{(10)}$ Penelitian lain menunjukkan hasil yang berbeda, di mana dalam penelitian tersebut menunjukkan adanya hubungan antara status pernikahan dengan domain psikologis dan seksual. ${ }^{(12)}$ Keberadaan pasangan hidup dapat dijadikan sebagai dukungan sosial dalam menghadapi perubahan selama masa menopause. Perempuan yang tinggal bersama pasangan maupun janda atau bercerai sebagian besar memiliki kategori cukup pada domain psikologi, fisik, sosial dan seksual. ${ }^{(12)}$ Dukungan sosial keluarga dapat membantu seorang perempuan menopause dalam memahami dan mengatasi perubahan hidup yang sedang dialami. ${ }^{(13)}$ Orang dengan dukungan sosial keluarga yang tinggi dapat mengalami penurunan level stres dan kemudian menimbulkan koping terhadap stres yang selanjutnya akan tercipta keberhasilan beradaptasi. $^{(14)}$ Selama penelitian didapatkan informasi bahwa meskipun seorang perempuan tidak tinggal 
bersama pasangan hidup lagi namun masih ada anak-anak yang bisa dijadikan sumber dukungan sosial sehingga tidak memengaruhi kualitas hidup perempuan klimakterik.

Penelitian ini menunjukkan bahwa tingkat pendidikan tidak berpengaruh secara signifikan terhadap kualitas hidup perempuan klimakterik. Hasil penelitian ini mendukung hasil penelitian sebelumnya yang menyatakan bahwa tingkat pendidikan tidak berhubungan dengan kualitas hidup penderita kanker payudara pasca mastektomi. ${ }^{(7)}$ Tingkat pendidikan penderita kanker payudara tidak berpengaruh terhadap kualitas hidup penderita kanker payudara pasca mastektomi. ${ }^{(15,16)}$ Hasil penelitian ini berbeda dengan penelitian sebelumnya yang menunjukkan bahwa tingkat pendidikan akan berpengaruh secara signifikan terhadap domain fisik dan psikososial. ${ }^{(10)}$ Perbedaan hasil penelitian ini terletak pada usia responden, di mana usia responden dalam penelitian sebelumnya adalah 40-60 tahun, dan penggunaan kuesioner kualitas hidup. ${ }^{(10)}$

Hasil penelitian ini menyatakan bahwa tingkat penghasilan tidak berpengaruh terhadap kualitas hidup perempuan klimakterik. Hasil penelitian ini mendukung penelitian sebelumnya yang menyatakan bahwa tingkat pendapatan tidak berpengaruh terhadap kualitas hidup perempuan premenopause dan pascamenopause. ${ }^{(9)}$ Hasil tersebut berbeda dengan penelitian sebelumnya yang menunjukkan bahwa tingkat penghasilan berpengaruh secara signifikan terhadap domain psikososial dan seksual. ${ }^{(10)}$ Hal tersebut disebabkan oleh beberapa perbedaan dalam hal gaya hidup sehari hari dalam pemenuhan kebutuhan hidup dan kuesioner kualitas hidup yang digunakan juga berbeda.

Penelitian ini menunjukkan bahwa status pekerjaan berhubungan secara signifikan dengan kualitas hidup perempuan klimakterik. Hasil penelitian ini berbeda dengan hasil penelitian sebelumnya yang menyatakan bahwa status pekerjaan tidak berhubungan dengan kualitas hidup penderita kanker payudara pasca mastektomi. ${ }^{(7)}$ Hasil penelitian yang sama mengatakan bahwa perempuan yang bekerja tidak sempat memikirkan kesehatannya menyangkut klimakterium dan menopause yang akan ataupun yang sudah dialaminya, apalagi mereka tahu bahwa menopause akan dialami oleh semua perempuan sehingga masalah menopause merupakan hal yang biasa. $^{(17)}$ Begitu juga dengan perempuan yang tidak bekerja. Secara formal mereka tidak bekerja, namun pekerjaan rumah tangga cukup membuatnya sibuk, sehingga mereka juga tidak sempat memikirkan menopause. Hasil penelitian ini juga mendukung penelitian sebelumnya yang menyatakan bahwa status pekerjaan akan memengaruhi domain fisik dan psikososial saja. ${ }^{(10)}$ Ibu rumah tangga mempunyai kualitas hidup yang lebih rendah dibandingkan dengan perempuan yang bekerja. ${ }^{(1)} \mathrm{Hal}$ 
tersebut karena perempuan yang bekerja akan mempunyai hubungan sosial yang lebih kuat sehingga tidak hanya mempunyai harga diri yang lebih tinggi, tapi juga dukungan sosial dan kualitas hidup yang lebih baik.

Penelitian ini juga menunjukkan bahwa paritas berpengaruh terhadap kualitas hidup perempuan klimakterik. Paritas akan memengaruhi kualitas hidup pada domain seksual. ${ }^{(10)}$ Dukungan sosial yang didapatkan oleh responden tidak hanya berasal dari suami, namun juga bisa berasal dari anggota keluarga yang lain seperti anak-anak. Keberadaan anak-anak dalam suatu rumah tangga akan memberikan dukungan sosial bagi orangtua. Adanya dukungan sosial yang baik akan membantu perempuan klimakterik dalam beradaptasi terhadap perubahanperubahan dan gejala selama menopause sehingga mampu meningkatkan kualitas hidup.

Kepemilikan jaminan kesehatan tidak berpengaruh secara signifikan terhadap kualitas hidup perempuan klimakterik. Hal ini disebabkan meskipun mereka tidak memunyai jaminan kesehatan namun masih ada fasilitas kesehatan yang cukup dekat dan biaya terjangkau yang masih bisa dimanfaatkan oleh responden ketika merasakan keluhan pada dirinya. Beberapa responden menyampaikan bahwa meskipun mereka memunyai jaminan kesehatan namun mereka jarang menggunakannya.

\section{KESIMPULAN}

Paritas dan status pekerjaan berhubungan secara signifikan dengan kualitas hidup perempuan klimakterik.

\section{SARAN}

Bagi peneliti selanjutnya diharapkan perlunya dilakukan penelitian lebih lanjut tentang gejala menopause dan kualitas hidup perempuan klimakterik masing-masing fase menopause.

\section{KEPUSTAKAAN}

1. Blumel, JE, Branco, CC, Binfa, L., Gramegna, G., Tacla, X., Aracena, B., et al .. 2000 Quality of Life after the menopause: A Population Study. Maturity, 34, $17-23$

2. Senba N, Matsuo H. Effects of a health education program on climacteric women. Climacteric. 2010; 13: 561-569

3. Binfa. L., Munoz. L., Vergara, et al. Influence of psychosocial factors on climacteric symptoms. Maturitas. 2004; 48:425-31

4. Smith-Di Julio. K.., Woods. N.F., Mitchell. E.S. Well being during the menopausal trantition and early postmenopause : a within stage analysis. Women's health issues. 2008; 18:310-18

5. WHO. 1994. Quality of life assessment: International perspectives. Berlin: Springer

6. Nazir, K.A. 2006. Penilaian kualitas hidup pasien pasca bedah pintas koroner yang menjalani rehabilitasi fase III 
dengan menggunakan SF-36. Jakarta : Universitas Indonesia

7. Hanafi, Z.Z., 2010. Faktor-faktor yang memengaruhi kualitas hidup penderita kanker payudara pasca kemoterapi adjuvan di RSUP Dr. Sardjito Yogyakarta. Karya Tulis Paripurna. Bagian IImu Bedah Fk UGM Yogyakarta

8. Geiger, A.M., West, C.N., Nekhlyudov, L., Herrinton, L.J. Contentment With Quality of Life Among Breast Cancer Survivors with and Without Contralateral Prophylactic Mastectomy. J Clin Oncol 2006;24:1350-1356

9. Ozkan, S., Alatas, e.R.m Zencir, M. Women's Quality of Life in the Premenopausal and Postmenopausal Women. Quality of Life Research (2005)14:1795-1801

10. Kalarhoudi, M.A., Taebi, M., Sadat, Z., Saberi, F. Assessment of quality of life in menopausal periods : A population study in Kashan, Iran. Iran Red Crescent Med J. 2011; 13(11):811-817

11. Silva, A.R., Tanaka, A.C.D. Factors associated with menopausal symptom severity in middle-aged Brazilian women from the Brazilian western Amazon. Maturitas. 2013; 76: 64-69
12. Ehsanpour, S., Eivazi, M., Davazdah., Emami, SH. Quality of life after menopause and its relation with marital status. Iranian Journal of Nursing and Midwifery Research. 2007;12: 130-5

13. Baltimore, M., Brynes, G., Watkins, C. 2004. Approaching Menopause. Diakses tanggal 25 April 2013 dari http://baltimorepsych.com/menopause

14. Taylor, S.E. 1995. Health Psychology. $3^{\text {rd }}$ edition. United States of America: Mc Graw-Hill

15. Sumanta, Aryandono, T. 2008. Kualitas Hidup Penderita Karsinoma Mammae pasca Operasi di RS Sardjito. Dalam Karya IImiah Paripurna PPDS I IImu Bedah FK UGM

16. Meyers, C.A., Weitzner, M.A., Stuebing, K.K., Saleeba, A.K. 1997. Relationship between Quality of Life and Mood in Long Term Survivors of Breast Cancer Treated with Mastectomy. Departement of Neuro Oncology, Texas University. Supportive care in Cancer. 5(3):241-8

17. Indiati, A., Haditono, S.R., Hadi, S. Sikap wanita terhadap menopause : ditinjau dari kondisi dan status kerja. Berkala Penelitian Pascasarjana. UGM. 2001.Vol.4 No 2A, 323-339 